reference has already been made in Nature (see NATURE of March 4, p. 386). The report is fully illustrated and accompanied by plans. Mr. James Hornell draws on his world-wide knowledge of the construction of various forms of boat to trace the plank-built boat to its origin. Among the interesting shorter notes which are always a feature of the contents, mention should be made on this occasion of a valuable suggestion from Mr. Stanley Casson, urging the prosecution of submarine research in the coastal waters of Greece. He points out that not only are the sea routes of antiquity well known, but recent discoveries of statuary, especially bronzes of the best period of classical art, support the argument that cargoes of artistic loot on the way to Rome may have been lost with some frequency.

\section{Design of Electric Power Stations}

AN important paper by F. W. Lawton was read to the Institution of Electrical Engineers on March 9 dealing with the design of Hams Hall power station at Birmingham, designed twelve years ago, and with a new Hams Hall power station $B$ which will be constructed shortly for the same purpose and on a neighbouring site. The author stresses the point that from the time when the calculations for a proposed power station are made until it is completed and running on a commercial load, several years may have elapsed and great changes may have occurred. For example, the average price of the coal used in the furnaces is now $17 s$. per ton as against $9 s .6 d$. in 1935 . In designing the new station it was reasonable to consider which features of the old station should be repeated and which rejected in the new station built twelve years afterwards. During this time coal prices have increased, high voltages have become normal and the progress made in metallurgy has made much higher steam temperatures feasible. All these changes call for modification in the designs if the best efficiency and economy are to be obtained. As regards the general lay-out, the simplicity and uniformity of the existing station will be repeated. There is a single row of boilers parallel to a single end-on row of turbo alternators. Electrostatic flue-gas cleaning plant will be retained. The absence of architectural adornment of the new buildings will be more rigorously enforced. Air raid precautions insist that there must be no roof lights or external windows to basements. For economic reasons the superstructure will be made of ferro-concrete instead of structural steel. Turboalternators of $50,000 \mathrm{kw}$. capacity each will again be used in the new station, but they will generate at 33,000 volts instead of at 11,000 volts as in the present station. A true understanding of what is real economy is obscured by the ever-changing technology of power production, by the difficulties of accurately forecasting operating conditions many years ahead, and by reactions of local trade developments.

\section{Research at the Kodak Laboratories}

ThiRTX-NINe papers are covered in the recently published "Abridged Scientific Publications from Kodak Research Laboratories" (vol. 19. Pp. viii +
288. Rochester, New York : Eastman Kodak Co.). The wide variety of subjects studied at the Kodak Laboratories is well illustrated. Most of the papers have some obvious connexion with photographic manufacture or technique. Among these may be mentioned specially four papers dealing with the measurement of photographic density. This has never yet been standardized and, though for most technical purposes 'density' is sufficiently well understood to permit useful application of measurement to laboratory testing and works control, yet for precise comparison of results obtained on different instruments of slightly different design, there is need for much further progress. Perhaps the new information may be useful in achieving this. There are, however, several papers which are devoted to subjects which are outside the photographic field altogether, and here we may cite a group of papers by Dr. K. C. D. Hickman and colleagues dealing with fractional distillation of phlegmatic liquids. The work has resulted in development of much improved apparatus for distillation of vitamins. As with previous volumes, each paper is presented without drastic shortening, so that to those who are not able to turn to the full papers in their original journals the volume is of exceptional value.

\section{Scottish Wild-Life Preservation}

The Council of the Zoological Society of Scotland recently set up a Scottish Nature Reserve Committee, on which various public bodies are represented, for the purpose of promoting the preservation of Scottish wild-life. The Committee wishes to obtain full and accurate information regarding the existence, numbers, increase or decrease, and generally the most complete statistics, of native species in different parts of the country. The Committee believes that helpful information of this kind could be furnished by local natural history societies and other associations as well as by landowners, gamekeepers and others, and, therefore, it desires the co-operation of anyone who could furnish such information and who would collaborate with the Committee in the work which it hopes to do. Another aspect of the work which the Committee might usefully undertake would be the mapping out of areas in Scotland which might be suitable for Nature reserves or sanctuaries. Anyone who possesses local knowledge of the suitability of land for such a purpose could greatly assist the Committee by communicating such information to it. Communications should be sent to the DirectorSecretary, the Zoological Society of Scotland, Zoological Park, Edinburgh, 12.

\section{Biology and Social Studies}

Fact, now successfully at the end of two years' activity, which produces, in its own phrase, "A monograph a month", has just brought out another scientific number bearing the title "Biology and Man : Past and Future" by Prof. Marcel Prenant of the Sorbonne. This for the most part consists of an interesting and well-written summary of the main trends in the history of biology in relation to 
contemporary social and economic backgrounds. This is seconded by an able essay from Dr. H. J. Muller, who is well known as a geneticist, now of Edinburgh, entitled "The Dominance of Economics over Eugenics" in which the relationship of social systems to human inheritance, and the true value of eugenic hopes, are discussed. He propounds the question whether the present social systems of western Europe do not involve a selection of socially inferior rather than of socially superior human material. These contributions should be of interest not only to all biologists, but also to much wider circles. Fact is edited by Mr. R. W. Postgate; Mr. H. G. Wells has recently joined its editorial board.

\section{Standards on Electronics and Radio Receivers}

The Institute of Radio Engineers (330 West 42nd Street, New York) was founded in 1912 to advance the theory and practice of radio and allied branches of engineering and to maintain a high professional standard amongst its members. Although dominantly in the United States of America, the Institute membership of more than 5,000 persons is distributed throughout the world. The Proceedings, published since 1913, is issued monthly and contains contributions from leading workers in the theoretical and practical fields of radio communication. It has co-operated with many other bodies in the establishment of standards. It has published many reports dealing with the definitions of terms, letter and graphical symbols, and methods of testing and rating equipment. Now it has issued "Standards on Electronics, 1938" and "Standards on Radio Receivers, 1938" (price 50 cents each). The committees which drew up the pamphlets are to be congratulated on the thorough way they have done their work. Every radio engineer and teacher of technical electricity should have a copy of these pamphlets, for they are most useful for reference.

\section{Interplanetary Travel}

$W_{\mathrm{E}}$ have received vol. 5, No. 1 of the Journal of the British Interplanetary Society, a body "founded for the stimulation of public interest in the possibility of interplanetary travel, the dissemination of knowledge concerning the problems which the epockmaking [sic] achievement of an extra-terrestrial voyage involves, and the conducting of practical research in connection with such problems". This number of the Journal contains designs for a "space ship" intended to perform a voyage to the moon and back. While we may invite the charge of obstructionism if we dismiss the whole affair as a wild-cat speculation, it is necessary for us to remark that, while the ratio of research results accomplished to speculative theorizing is so low, little confidence can be placed in the deliberations of the British Interplanetary Society.

\section{The Midwifery Service}

THe annual report of the Central Midwives Board or the year ended March 31, 1938, has been issued (London: H.M. Stationery Office. 4d. net). At the end of the year, there were 67,089 women on the midwives roll, a net increase of 2,043 on the total for the previous year, but only a little more than a quarter of the total number of those on the roll are engaged in the practice of their profession. The number of candidates entering for the examination was 4,420 , the highest number ever recorded, of whom three quarters were successful. The report sets out the arrangements made by the Board for the approval of institutions, lecturers and teachers under the rules, of which a detailed explanation is given.

\section{Science Abstracts}

Nerther science nor industry is standing still and to anyone who wishes to keep abreast of the advances made, the two sections of Science Abstracts-Physics and Electrical Engineering-are of great service. The two index numbers published in the last week of February completed the volumes for 1938. The Physics Section contains 5,081 abstracts from about half that number of publications, the average number of the abstracts being about $4 \cdot 3$ per page. The index of subjects covers 189 pages, that of apparatus 22, and the author index 65 pages. The Electrical Engineering Section has 3,622 abstracts, about $4 \cdot 6$ to a page, with a subject index of 59 pages and an author index of 31 pages. The Physics volume is thus about 10 per cent less than, and the Electrical Engineering volume about 3 per cent larger than, the volume for 1937 .

\section{British Empire Cancer Campaign}

ThE seventieth quarterly meeting of the Grand Council of the British Empire Cancer Campaign was held on April 3. The following grants were approved, making a total to date for the year 1939 of more than $£ 48,000$ : $£ 1,000$ to the North of England Branch of the Campaign for the continuation of the special short-wave investigations being carried out under the direction of Dr. F. Dickens; and $£ 160$ to Mr. E. Nevill Willmer, working at the University of Cambridge. The Council received a report regarding the joint discussions which had taken place between representatives of the Campaign, the Medical Research Council and the National Radium Commission on the subject of the installation of a cyclotron in Great Britain primarily for medical and biological investigations as affecting the cancer problem. The three bodies have now jointly agreed to refer this matter for further consideration to the Radiology Committee. A further sum of approximately $£ 6,500$ is to be allocated to meet the expenses to be incurred during the second year's working of the scheme of the Clinical Cancer Research Committee. This scheme covers an inquiry into all fresh cases of cancer in the London area, and during the first two years the results of investigations into approximately 34,000 cases will have been placed at the disposal of the Committee. Dr. J. M. Woodburn Morison has been invited to become the representative of the Campaign on the Scientific Advisory Committee of the newly amalgamated Radium Institute and Mount Vernon Hospital. 